\title{
GEOCHEMICAL ASSESSMENT OF INFLUENCE OF URBANIZATION ON HEAVY METAL ENRICHMENT IN STREAM SEDIMENTS OF ONDO TOWN, SOUTHWESTERN NIGERIA
}

\author{
I. T. ASOWATA, A. F. ABIMBOLA, B. A. KOMOLAFE AND L. H. ADEPEKO
}

(Received 26 April 2014; Revision Accepted 28 July 2014)

\begin{abstract}
Trace element enrichment and pollution caused by urbanization with its associated effects increasingly becoming a great threat to environmental and human health. This paper, sediments from streams that drain Ondo town were sampled to evaluate the potential effects of urbanization on trace element accumulation in stream sediments. Fifty (50) samples of stream sediments samples were collected along the main stream and other adjoining streams in the town, wet sieved, digested and analyzed by Inductively coupled plasma- Atomic emission spectrometer (ICP-AES) for trace element $(\mathrm{Cu}, \mathrm{Zn}, \mathrm{Pb}, \mathrm{Cd}, \mathrm{Cr}$,).. The result of the concentration of trace elements in ppm showed in the order of distribution: $\mathrm{Cu}$ (1-114); Pb (3-214); Zn (8-1332); Ni (1-17); Co (1-20); Mn (26-1699); Th (3-16); Sr (5-145); Cd (0.51.4); V (3-188); $\mathrm{La}$ (11-51); $\mathrm{Cr}(2-116) ;$ and $\mathrm{Ba}$ (40-337). From the result, several hot-spot areas were identified. These hot-spots were identified to be located close to areas where activities like, vehicle related workshops, road junctions, municipal waste, abattoir and farm gardens. Except for some of the elements, such as $\mathrm{Cd}$, Sr and Th, which shows low concentration, the rest of the heavy metals in the stream sediments had two to three folds of magnitude of the concentration compare with the limits values of Granite, Migmatite and Average Shale samples. Principal component analyses (PCA) and geoaccumulation Index (Igeo) of the compositional data, slightly shows presence of metal contamination except $\mathrm{Cd}, \mathrm{Sr}$ and Th which are ascribed to anthropogenic activities. $\mathrm{Pb}, \mathrm{Zn}, \mathrm{Cu}, \mathrm{Cr}, \mathrm{Mn}, \mathrm{Ni}$ and $\mathrm{V}$ positively correlated with each other $(R=0.51-0.95)$, which indicate analogous sources of geochemistry characteristics.
\end{abstract}

KEYWORDS: Ondo town, Sediment, Geo-accumulation index, Urbanization, Hot-spot.

\section{INTRODUCTION}

As the world's urban population continues to grow, it becomes increasingly imperative to understand the dynamic interactions between human activities and the urban environment. The development of urban environmental geochemistry has yielded a significant volume of scientific information about geochemical phenomena found uniquely in the urban environment, such as the distribution, dispersion, and geochemical characteristics of some toxic and potentially toxic trace metals as stated by (Wong,et al, 2006 Gbadebo, 2007, Baruah and Khare, 2009; 2010, Lee, et al., 2005). Urban activities have a significant negative impact on the environment, particularly on aquatic resources as well as other biota. Stream Sediments are classic materials that are derived from the parent bed rock, as well as sand and deposited particles. Most sediments that are often transported through streams with continues transportation to various location or depositional environment, serve as ecologically important systems that provide diverse habitats for aquatic biota but because of their usefulness, physicochemical characteristics and their relative flows, they are susceptible to contaminant retention, that may eventually lead to potentially harmful elements. Stream suspended and bottom sediments contain significant high concentration of metals than those found in the host water, because they serve as sink for these elements which may directly affect overlying waters, shallow ground water, as well as vegetation around the area, affecting human and livestock lives. (Samarghandi, et. al. 2007; Seshan et. al. 2010, Olatunji and Abimbola 2010, Baruah and Khare, 2010, Yaun, et al., 2011). Hence stream sediment becomes important media for assessing the influence of urban growth. Ondo metropolis is one of the many cities in Nigeria that have continued to witness tremendous growth in human population, which has also led to increase in her associated consumables. Market places, high waste generated, increased vehicular activities, raw material processing industries, sawmill abattoir and waste metal recycling company. All these activities result in generation and accumulation of waste, which eventually finds it ways into most of these drainages because of obvious non- regulation of waste disposal by government authorities. Ondo metropolis is the second largest city in ondo state, with a dentritic drainage system, where most of these streams empty into the Isalewa river which is the main river in the city. All

I. T. ASOWATA, Department of Physical Sciences, Wesley University of Science and Technology, Ondo, Nigeria.

A. F. ABIMBOLA, Department of Geology, University of Ibadan, Ibadan, Nigeria

B. A. KOMOLAFE, Department of Physical Sciences, Wesley University of Science and Technology, Ondo, Nigeria.

L. H. ADEPEKO, Department of Physical Sciences, Wesley University of Science and Technology, Ondo, Nigeria. 
runoff surface waters that cannot percolate or infiltrate into the ground, empty into this river, with attendant redistribution of sediments in the river channels. The city lies within longitudes $7^{\circ} .00^{l}$ to $7^{\circ} .06^{\prime}$ and Latitude $4^{\circ} 47^{\prime}$ to $4^{\circ}$. $53^{l}$. (Fig 1) it is connected in the south through road by Ore, in the East by Akure, in the north by Ileluji and in the west by lle-Ife, Okegbo town, with an average distance of between $25 \mathrm{~km}$ to $45 \mathrm{~km}$ to all these cities. The city cover's an average land area of $40 \mathrm{~km}^{2}$. The city is made up of towns like Surulere, Valentino, Funbi-Fagun, Ademalagun express way, Yaba, Sabo, Oka, Itanla, Nipakala, and many others towns that developed to form the city.
The objectives of this study were to determine the concentrations of metals in the stream sediments that drain the study area, to assess the geochemical distribution of these elements as well as evaluate for pollution status of the elements using statistical quantification indices.

The geology of the study area consists of Precambrian igneous and metamorphic rocks (Migmatite, Igneous and Quartzite) that is at discreet location seen as low lying outcrop in some areas, while in some other areas, they occur as massive and extensive. The mineralogy consists of Biotie, feldspar, quartz and muscovite minerals.

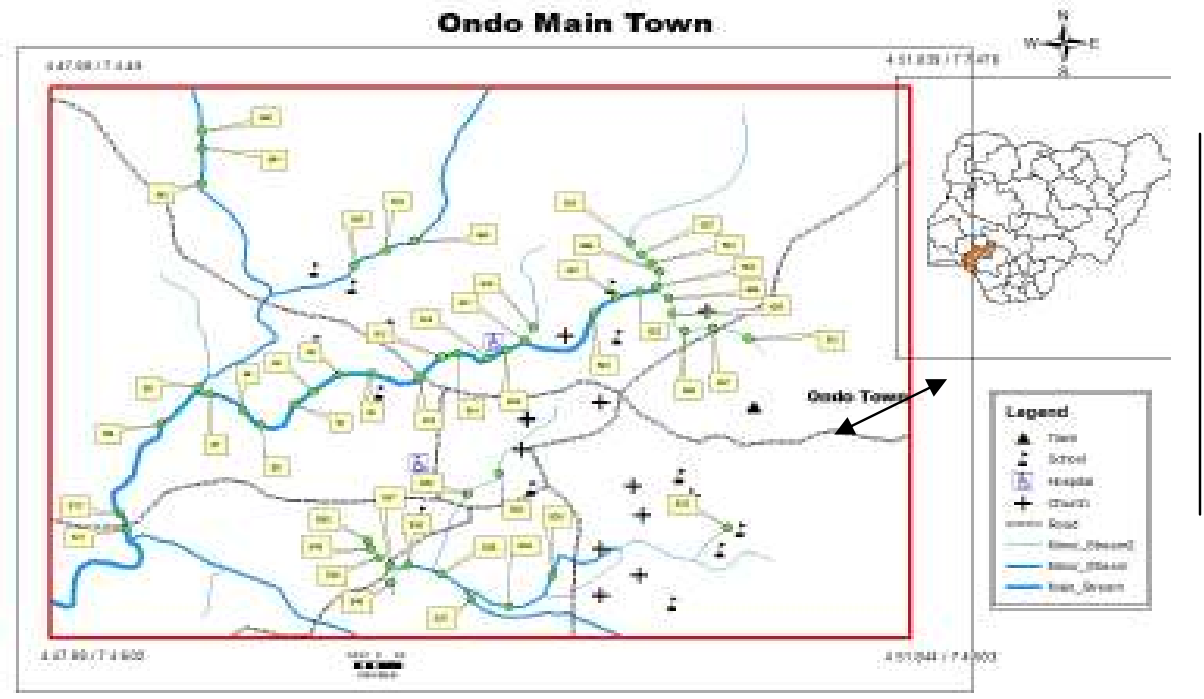

Fig1: Sampling locations of the study area (Modified Sheet 263, Federal Survey Nigeria, 1968)

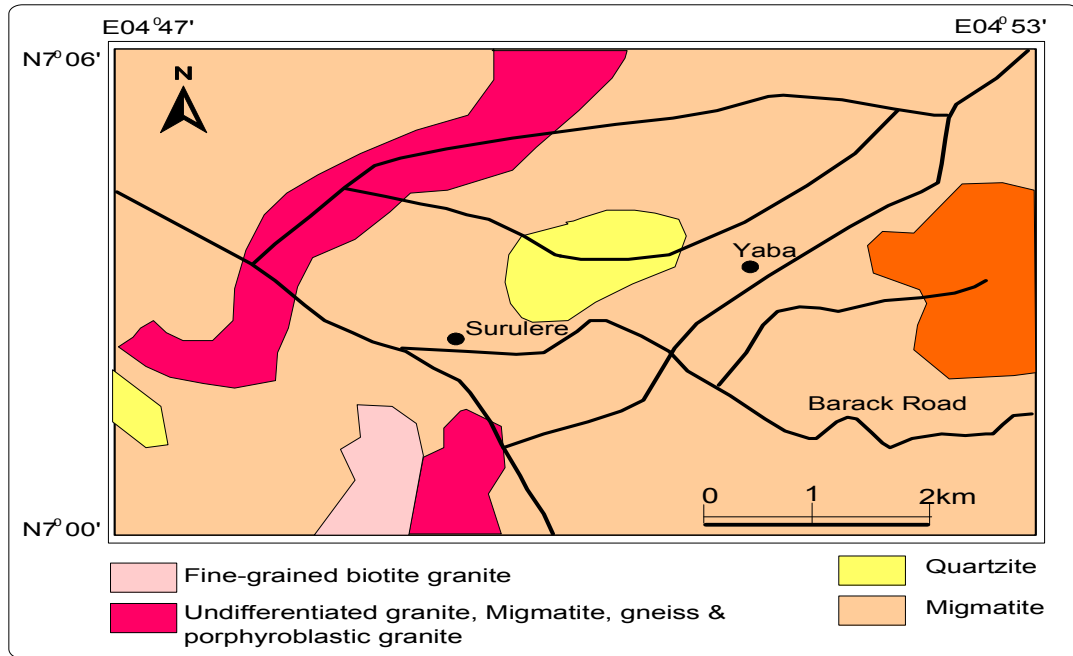

Fig2: Geologic map of the study area (Modified after NGSA generalised geologic map of Nigeria, 2006)

\section{MATERIALS AND METHODS}

A total of fifty (50) stream sediment samples were collected from some of the streams that traverse the study area, including the main stream which is known as Isalewa River (fig. 2). The samples were collected at interval of between $200 \mathrm{~m}$ to $300 \mathrm{~m}$ using plastic packer to avoid contamination of samples. At each site, 3-4 sub-samples in the area of about $10 \mathrm{~m}$ radius from both sides of the river's sampling point, were obtained and mixed to yield a composite 
sample and wet sieving was carried out at each location using <200um sieve mesh to get the silt-clay fraction.

The wet samples were stored in the field in a plastic bottle of $75 \mathrm{cl}$. All the samples were allowed to settle down, and the suspended water was decanted. After-ward, they where air dried and homogenized in an agate mortar, disaggregated, ground and further sieved with < 63um for subsequent sample digestion and chemical analyses. The samples where digested using, Aqua-regia digestion $\left(0.5 \mathrm{ml} \mathrm{H}_{2} \mathrm{O},\right) .6 \mathrm{ml}$ concentrated $\mathrm{HNO}_{3}$ and $1.8 \mathrm{ml} \mathrm{HCL}$ ) for 2 hours at $95^{\circ} \mathrm{C}$. Thereafter, the samples were cooled and then diluted to $10 \mathrm{ml}$ with deionize water and homogenized, then they were analyzed to determine the constituents of the elements using inductively coupled plasma- optical emission spectroscopy (ICP-OES) at the Geochemical Laboratory of ACME laboratory Limited, Vancouver, Canada. $\mathrm{pH}$, Electrical Conductivity (EC) and Total Dissolve Solid (TDS) values were obtained with a standard multi physico-chemical determinant meter (Hach Eco40 multi Milwaukee), from slurries prepared using $20 \mathrm{~g}$ of samples and $20 \mathrm{ml}$ of distilled water

\section{RESULTS AND DISCUSSION}

It is interesting for the proper understanding of the effect of urbanization on surface earth media, using the background as a measure is of importance. Hence the natural (normal) concentration of trace elements in sediments is of great interest, which will be needed to assess the degree of sediment contamination in other to evaluate the sediment quality, which is a prerequisite for sustainable land use and management. As we already know, there is no one natural background level for any solid material, in or on the earth, because the earth is characterized by non-homogenous, according to (Eby 2004, Hamzeh et al. 2011). So, in environmental geochemistry studies, natural background values must be evaluated on a local scale. Using published work on the average values of soils, sediments, rock and water can be conventionally accepted. In this work, the average shale concentration, the elemental concentration two main rock types that underlain the study area (i.e Granite and Migmatite rocks) as well as relative variation on trace elements from one location to another particularly these location that of low human activities were used to measure enrichment status of the sediments in the study area.

The statistic summary result of trace element concentration in (units: ppm) of Ondo stream sediments is presented in (Table:1). The stream sediments showed a significant heterogeneity in the concentrations of the elements being studied, with the obvious spatial variation of concentratons from one sample location to another.

Mn exhibits the highest concentration in (unit: = $\mathrm{ppm}$ ) in the stream sediments( range $=26-1699$, arithmetic mean \pm standard deviation $=519.6 \pm 322.2$ ), followed by $\mathrm{Zn}$, (8-1332, mean $489.9 \pm 359.6$ ), Ba (40300 mean152.6 \pm 55.4,$)$, $\mathrm{Pb}(3-214$, mean $78.7 \pm 48.4)$, $\mathrm{V}(3-188$, mean $59.2 \pm 25.1)$, Sr (5-145, mean $43.6 \pm$
31.8), Cr (2-116, mean $36.6 \pm 16.8)$, Cu (1-114, mean $36.5 \pm 26.3)$, La (11-51, mean $30.1 \pm 8.5)$, and Co (120 , mean $20 \pm 3.1)$. The mean concentration were below $8.9 \mathrm{ppm}$ for $\mathrm{Ni}$, below 10.2ppm for $\mathrm{Th}$ and below $0.7 p p m$ for $\mathrm{Cd}$.

Comparing the results of the concentration of trace elements in the various locations with the analised results from two dominant rock types in the study area i.e the migmatite and granitic rock as well as the concentration of uncontaminated average shale values, shows that stream sediment in ondo town, are enriched in some locations of the trace element investigated. Arithmetic mean concentration of stream sediments were three times higher for $\mathrm{Zn}$ and $\mathrm{Pb}$, two times higher for Cd compare to those of stream sediments (Table1). Again when one observe comparatively, the concentration of the studied elements in the two rock types are lower than the mean concentration for $\mathrm{Cu}, \mathrm{Pb}$, $\mathrm{Zn}$ and the other elements being studied. From the results, it is observed for $\mathrm{Mn}$, with the exception of location's (SS) 2, 40, 41, 43, 45 and 49, which has elemental concentration less than 120ppm. The other locations have concentration higher than 250ppm, with the highest location in SS9 (1699ppm). Other hot spots are in location (SS) 1, 4, 7, 11, 26, 34, 36, 44 and 49.

$\mathrm{Zn}$ concentration in the study area are relatively high in most locations. Few location with low elemental concentration include (SS) 2, 26, 27, 28, 30, 40, 41, 42, $42,43,44,45,49$ and 50 . These areas have elemental concentration lower than 200ppm. All other locations are characterized with high $\mathrm{Zn}$ concentration higher than 200ppm. Some of the hot spots include, (SS) 1, 20, $32,34,35,37,39,48$, and 33 . With the highest in location 33 (1332ppm). These locations have $\mathrm{Zn}$ concentration higher than $800 \mathrm{ppm}$.

Lead $(\mathrm{Pb})$ concentration determined in the study area are found to be high in similar locations compare to $\mathrm{Zn}$ and $\mathrm{Mn}$ locations that are observed to be hot spot, showing the same trend of elemental concentration. With the exception of locations (SS) 2 , $10,26,27,28,40,41,42,43,44,45$, and 49, which have $\mathrm{Pb}$ concentration lower than $45 \mathrm{ppm}$. Other locations have $\mathrm{Pb}$ concentration higher than 50pp. some of the hot spots include locations 12, 13, 23, 25, 32, 33, 35, 37, 39, 47 and 48. The higher concentration is in location $33(214 \mathrm{ppm})$. The other elements i.e Ba, $\mathrm{V}, \mathrm{Cr}, \mathrm{Ni}, \mathrm{Co}, \mathrm{La}, \mathrm{Th}, \mathrm{Sr}$, and $\mathrm{Cd}$, also shows spatial distribution of trace metal concentration from the samples analyses. These distributions align with the effect of urban activities, (areas close to waste dump, vehicular activities, farm lands, domestic emissions, wear and tear of vulcanized rubber tires) areas of high elemental concentration almost follow the same trend for most of the metals observed. The relative pervasive general metal enrichment in almost all the locations for $\mathrm{Pb}, \mathrm{Mn}$ and $\mathrm{Zn}$ suggest high effect of urban activities. Severe contamination appear to be of the same trend in most localities for $\mathrm{Mn}, \mathrm{Zn}$ and $\mathrm{Pb}$, suggesting noticeable pollution in the major stream of the area which drain North to South of the city, because of its high influx of waste draining into the main stream. 
Table1: Descriptive statistics of trace element concentration (ppm) in stream sediment of the study area

\begin{tabular}{|c|c|c|c|c|c|c|c|c|}
\hline Elements & $\mathrm{N}$ & Minimum (ppm) & Maximum (p & Mean & Std. Devia & ASC (ppm) & MGT & GT $\quad p p m$ \\
\hline $\mathrm{Cu}$ & 50 & 1 & 114 & 36.5 & 26.3 & 50 & 10 & 20 \\
\hline $\mathrm{Pb}$ & 50 & 3 & 214 & 78.7 & 48.4 & 20 & 50 & 13 \\
\hline $\mathrm{Zn}$ & 50 & 8 & 1332 & 489.9 & 359.6 & 90 & 100 & 77 \\
\hline $\mathrm{Ni}$ & 50 & 1 & 17 & 8.9 & 3.8 & 80 & $<2$ & 5 \\
\hline Co & 50 & 1 & 20 & 5.4 & 3.1 & 20 & 4 & 4 \\
\hline $\mathrm{Mn}$ & 50 & 26 & 1699 & 519.6 & 322.2 & 850 & 62 & 81 \\
\hline Th & 50 & 3 & 16 & 10.2 & 2.6 & 12 & 3.5 & 6.0 \\
\hline $\mathrm{Sr}$ & 50 & 5 & 145 & 43.6 & 31.8 & 400 & 391 & 230 \\
\hline $\mathrm{Cd}$ & 50 & 0.5 & 1.4 & 0.7 & 0.3 & 0.3 & $<0.5$ & $<0.5$ \\
\hline V & 50 & 3 & 188 & 59.2 & 25.1 & 130 & 13 & \\
\hline $\mathrm{La}$ & 50 & 11 & 51 & 30.1 & 8.5 & 40 & 39 & 5.3 \\
\hline $\mathrm{Cr}$ & 50 & 2 & 116 & 36.6 & 16.8 & 100 & $<2$ & 21 \\
\hline $\mathrm{Ba}$ & 50 & 40 & 337 & 152.6 & 55.4 & 600 & 82.7 & 61 \\
\hline EC (us/cm) & 50 & 89 & 211.0 & 158.4 & & - & & \\
\hline TDS (Mg/L & 50 & 66.8 & 158.3 & 118.8 & & - & & \\
\hline $\mathrm{pH}$ & 50 & 5 & 8.4 & 7.0 & & - & & \\
\hline
\end{tabular}

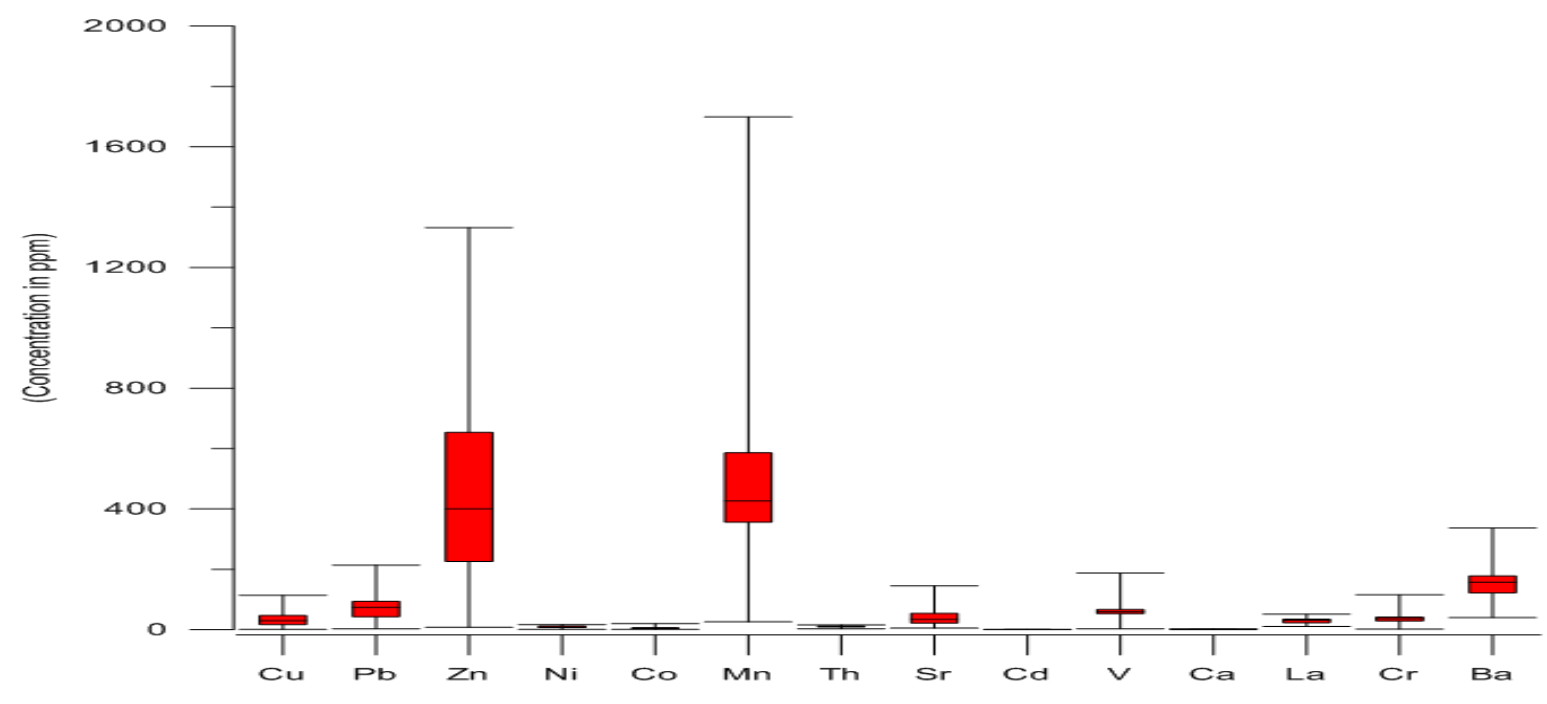

Elements

Fig3: Boxplots of the total concentrations (ppm) of trace elements in stream sediments. The central box represent $50 \%$ of the distribution, between the $25^{\text {th }}$ and $75^{\text {th }}$ percentiles. The line bisecting the central box is the median:the whiskers extend to the Max and Min of the distribution

\subsection{Statistical Analyses}

The results were further analyzed by statistical interpolations to ascertain trace elements relations in the stream sediments of the study area, between the various metal concentrations of the sediment samples. In the present study, both Pearson Correlation (PC) and Principal Component Analysis (PCA) were carried out using Origin and SPSS software package. In order to study the general characteristics of the stream sediments in Ondo town, the concentrations of trace metals content of the stream sediments were used as the input data in the PC and PCA.

The Pearson correlation showed a wide variation in the interelemental relationship both for the scatter plot and Correlation coefficients of the trace elements, fig4 (a-e) and Table 2. For the elemental relationship, there is a fair coefficient of determination $\left(R^{2}\right)$ between $M n$ and Co $\left(R^{2}=0.4179\right), \mathrm{Ni}$ and $\mathrm{Cr}\left(R^{2}=\right.$ $0.4855)$ and $\mathrm{Zn}$ and $\mathrm{Pb}\left(R^{2}=0.5821\right)$. While there is strong correlation between $\mathrm{Cu}$ and $\mathrm{Pb}\left(\mathrm{R}^{2}=0.6106\right)$ and $\mathrm{Zn}$ and $\mathrm{Ni}\left(\mathrm{R}^{2}=0.6704\right)$. These elements show close affinity suggesting analogous source of enrichment in the stream sediment.

The correlation matrix for the data obtained (Table 2) shows a wide variation in the correlation coefficient $(r)$ between element pairs. For example, the $r$ values range from -0.01 between $\mathrm{Th}$ and $\mathrm{Zn}$ to 0.95 between $\mathrm{V}$ and $\mathrm{Cr}$. Fairly strong to very strong positive correlation occurs among $\mathrm{Pb}, \mathrm{Cu}, \mathrm{Zn}, \mathrm{Ni}$ and $\mathrm{Sr}$. positively correlated with each other. Considerable high 
correlation were found between $\mathrm{Pb}$ and $\mathrm{Cu}(\mathrm{R}=0.78)$, $\mathrm{Zn}$ and $\mathrm{Cu}(\mathrm{R}=0.93), \mathrm{Zn}$ and $\mathrm{Pb}(0.76), \mathrm{Ni}$ and $\mathrm{Cu}(\mathrm{R}=$ $0.85), \mathrm{Ni}$ and $\mathrm{Pb}(\mathrm{R}=0.70), \mathrm{Ni}$ and $\mathrm{Zn}(\mathrm{R}=0.82), \mathrm{Cd}$ and $\mathrm{Sr}(\mathrm{R}=0.87)$ and $\mathrm{Cr}$ and $\mathrm{V}(\mathrm{R}=0.95)$. Other elements also showed fair to strong correlation as summarized in (Table 2).

Also the result obtained from the various PCA i.e (Factor analyses, three component plot and two component plot), (Table3, fig5a\&b) further found elemental association three and two component factors of association respectively. Factor analyses revealed three group of trace element, (Table3). the first group is made up of $\mathrm{Cu}, \mathrm{Pb}, \mathrm{Zn}, \mathrm{Ni}, \mathrm{Sr}, \mathrm{Cd}, \mathrm{Cr}$ and $\mathrm{Ba}$, accounting for $45 \%$ total variance of eigen value. These elements as also found in the correlation values (Table2), may have been enriched by same sources, most likely from domestic waste, effuents and vehicle related waste. The second group is made up of $\mathrm{Co}, \mathrm{Mn}$, Th and La, accounting for approximately $22.8 \%$ of the total variance. These elements may have been enriched in the sediments by activities relating to similar pollution source draining into the stream (e.g. urban waste). The third group consist of $\mathrm{V}$ and $\mathrm{Cr}$, which account for
$15.2 \%$ of the total variance. These two element main have been enriched in the sediment by same source, activities relating to soil weathering and leachate from automobile activities and other urban consumables like additives in chemical products. Table 4; shows summary of factor Analyses of the trace elements in stream sediements of Ondo town.

Applying the three and two plots of principal component analyses (PCA) enabled us to find out further that the same trace elements cluster close to each other i.e. those elements that are likely to be from analogous sources cluster together as summarily seen in fig $4(\mathrm{a} \& b)$. for the three component loading, $\mathrm{Cd}, \mathrm{Sr}$, $\mathrm{Cu}, \mathrm{Zn}, \mathrm{Pb}$ and $\mathrm{Ni}$ load close to each other suggesting similar source of enrichment. While La, Th, Mn, and Co load close to each other, also suggesting same source of enrichment. $\mathrm{Ba}$ appear on it own, suggesting an entire different source of enrichment. Also for the two component plot, it is observed that, the elements plot on two sides. These element further correlate base on the likelihood of their enrichment being from similar sources, fig4(a\&b)

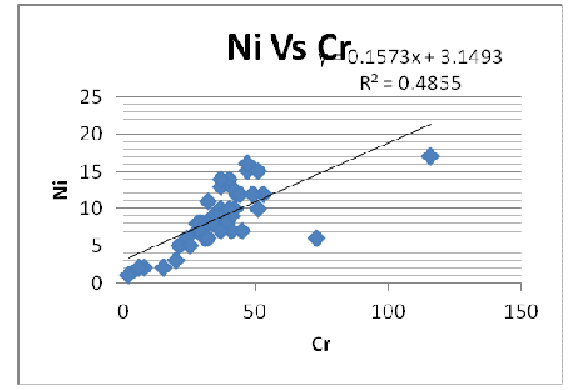

(a)

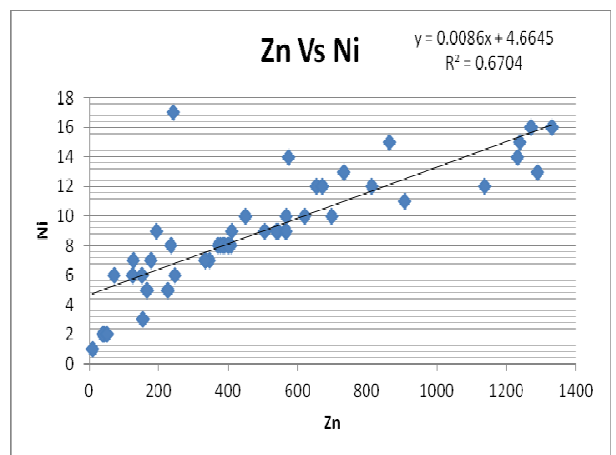

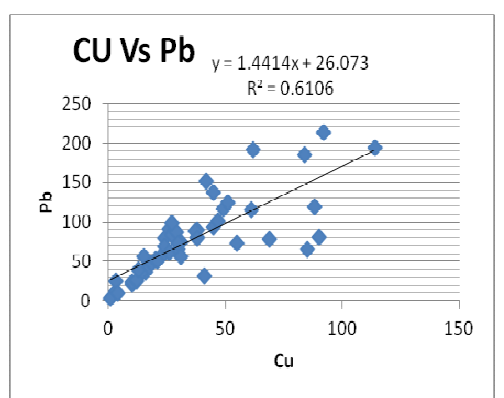

(b)

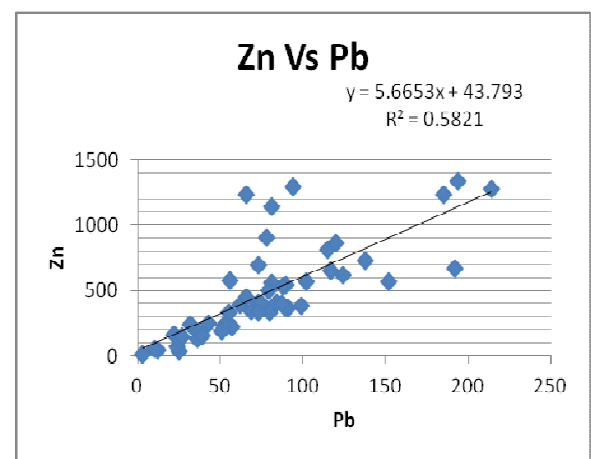

(d) 


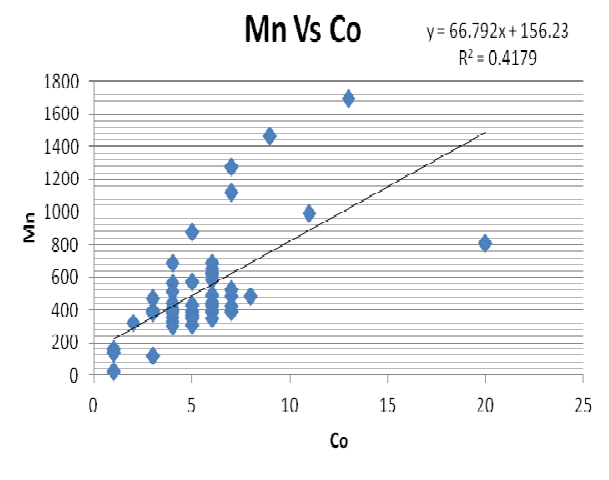

(e)

Fig4(a-e): Relationship between some of the trace elements in the stream sediments of the study area.

Table 2: Correlation coefficients of stream sediments in the study area

\begin{tabular}{|c|c|c|c|c|c|c|c|c|c|c|c|c|c|}
\hline & $\mathrm{Cu}$ & $\mathrm{Pb}$ & $\mathrm{Zn}$ & $\mathrm{Ni}$ & Co & $\mathrm{Mn}$ & Th & $\mathrm{Sr}$ & $\mathrm{Cd}$ & V & $\mathrm{La}$ & $\mathrm{Cr}$ & $\mathrm{Ba}$ \\
\hline $\mathrm{Cu}$ & 1 & & & & & & & & & & & & \\
\hline $\mathrm{Pb}$ & 0.78 & 1 & & & & & & & & & & & \\
\hline $\mathrm{Zn}$ & 0.93 & 0.76 & 1 & & & & & & & & & & \\
\hline $\mathrm{Ni}$ & 0.85 & 0.70 & 0.82 & 1 & & & & & & & & & \\
\hline Co & 0.01 & 0.02 & 0.20 & 0.24 & 1 & & & & & & & & \\
\hline $\mathrm{Mn}$ & -0.02 & 0.04 & 0.03 & 0.12 & 0.65 & 1 & & & & & & & \\
\hline Th & -0.04 & 0.13 & -0.01 & 0.29 & 0.38 & 0.27 & 1 & & & & & & \\
\hline $\mathrm{Sr}$ & 0.87 & 0.57 & 0.86 & 0.68 & -0.02 & -0.03 & -0.20 & 1 & & & & & \\
\hline $\mathrm{Cd}$ & 0.91 & 0.70 & 0.87 & 0.72 & -0.09 & -0.11 & -0.10 & 0.87 & 1 & & & & \\
\hline V & 0.29 & 0.18 & 0.18 & 0.64 & 0.24 & 0.13 & 0.55 & 0.12 & 0.15 & 1 & & & \\
\hline La & -0.10 & 0.02 & 0.06 & 0.17 & 0.69 & 0.48 & 0.61 & -0.11 & -0.18 & 0.19 & 1 & & \\
\hline $\mathrm{Cr}$ & 0.42 & 0.29 & 0.29 & 0.70 & 0.12 & 0.04 & 0.39 & 0.25 & 0.30 & 0.95 & 0.02 & 1 & \\
\hline $\mathrm{Ba}$ & 0.40 & 0.45 & 0.59 & 0.42 & 0.64 & 0.54 & 0.03 & 0.45 & 0.35 & -0.05 & 0.51 & -0.05 & 1 \\
\hline
\end{tabular}

Table 3: Summary of factor Analyses of the trace elements in stream sediments of the study area

\begin{tabular}{|l|l|l|l|l|}
\hline \multicolumn{5}{|l|}{ Extraction Method: Principal Component Analysis. } \\
\hline Elements & 1 & 2 & 3 & 4 \\
\hline $\mathrm{Cu}$ & $\mathbf{0 . 9 6}$ & -0.18 & 0.01 & -0.03 \\
\hline $\mathrm{Pb}$ & $\mathbf{0 . 7 9}$ & -0.04 & -0.06 & -0.36 \\
\hline $\mathrm{Zn}$ & $\mathbf{0 . 9 5}$ & -0.07 & -0.19 & -0.09 \\
\hline $\mathrm{Ni}$ & $\mathbf{0 . 9 2}$ & 0.20 & 0.24 & 0.00 \\
\hline $\mathrm{Co}$ & 0.17 & $\mathbf{0 . 8 2}$ & -0.33 & 0.19 \\
\hline $\mathrm{Mn}$ & 0.09 & $\mathbf{0 . 6 9}$ & -0.36 & 0.37 \\
\hline $\mathrm{Th}$ & 0.09 & $\mathbf{0 . 7 2}$ & 0.38 & -0.47 \\
\hline $\mathrm{Sr}$ & $\mathbf{0 . 8 8}$ & -0.28 & -0.17 & 0.13 \\
\hline $\mathrm{Cd}$ & $\mathbf{0 . 8 9}$ & -0.31 & -0.05 & -0.07 \\
\hline $\mathrm{V}$ & 0.40 & 0.47 & $\mathbf{0 . 7 5}$ & 0.19 \\
\hline $\mathrm{La}$ & 0.07 & $\mathbf{0 . 8 3}$ & -0.24 & -0.29 \\
\hline $\mathrm{Cr}$ & $\mathbf{0 . 5 0}$ & 0.29 & $\mathbf{0 . 7 5}$ & 0.25 \\
\hline $\mathrm{Ba}$ & $\mathbf{0 . 5 3}$ & 0.42 & -0.66 & 0.07 \\
\hline \% of Variance & 45.40029 & 22.80217 & 15.26634 & 5.329084 \\
\hline Total & 6.356041 & 3.192304 & 2.137288 & 0.746072 \\
\hline $\mathrm{Cumulative} \mathrm{\%}$ & 45.40029 & 68.20246 & 83.4688 & 88.79789 \\
\hline
\end{tabular}


Component Plot

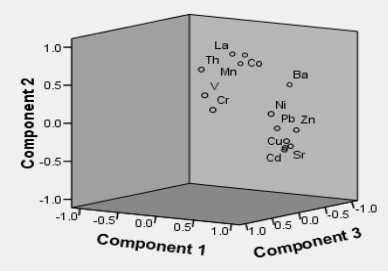

Fig5a: Plot of the three principle component for the trace elements

Component Plot

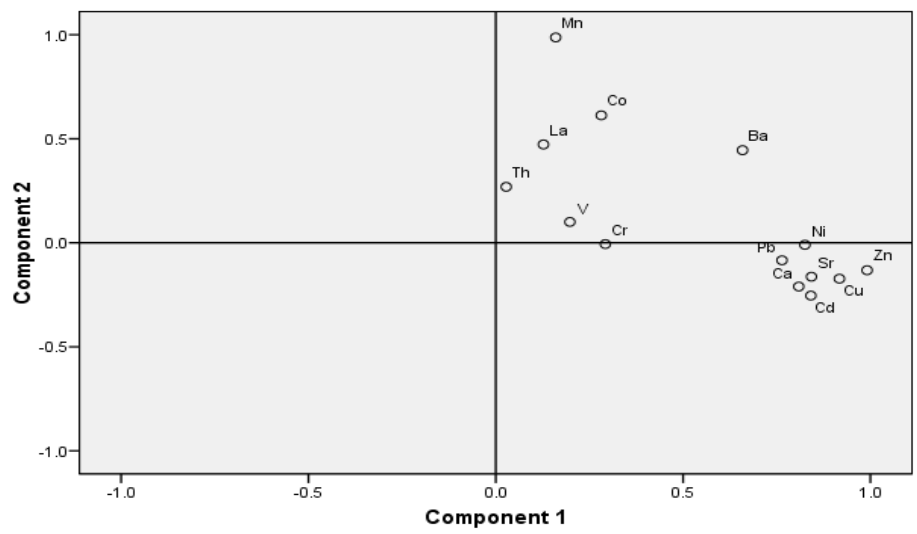

Fig5b: Plot of the two principle component for the trace elements concentration in stream sediments

The stream sediment quality assessment of the contamination status were evaluated using Geoaccumulation index. This method has been used successfully by researchers (Muller, 1979, Forstner and Wittmann, 1983 and Odewande and Abimbola, 2008) to determine the quality of the geo materials. It is expressed as

$\mathrm{I}_{\mathrm{geo}}=\log _{2} \mathrm{Cn} / 1.5 \mathrm{~B}_{\mathrm{n}}$
Where $I_{\text {geo }}$ represent the geo-accumulation index, $C_{n}$ represent measured concentration of the element in the sediment, $B_{n}$ represent the background value (where for this paper, the average shale value) and 1.5 is the backgraund matrix correlation. It is classified into six (6) classes (Muller, 1979), ranging from unpolluted to very highly polluted. The summary and details of the calculated Igeo from selected metals in the study area is presented in fig4 $(a$ and $b$ )

Table4a: Detailed Geo-accumulation Index Calculated for selected elements in stream sediments of Ondo town.

\begin{tabular}{|l|l|l|l|l|}
\hline S/N & $\lg \mathrm{Cu}$ & $\operatorname{lg~Pb}$ & $\lg \mathrm{Zn}$ & $\operatorname{lg~Cd}$ \\
\hline SS1 & 1.75 & 2.82 & 4.43 & 2.00 \\
\hline SS2 & -3.74 & -2.15 & -2.91 & 1.32 \\
\hline SS3 & 0.85 & 2.58 & 2.47 & 1.32 \\
\hline SS4 & 0.96 & 2.77 & 2.62 & 1.32 \\
\hline SS5 & 0.17 & 2.10 & 1.91 & 1.32 \\
\hline SS6 & 1.07 & 2.74 & 2.66 & 1.32 \\
\hline SS7 & 1.02 & 2.66 & 2.77 & 1.58 \\
\hline SS8 & 0.85 & 2.37 & 2.52 & 1.32 \\
\hline SS9 & 1.17 & 2.45 & 2.77 & 1.58 \\
\hline
\end{tabular}




\begin{tabular}{|l|l|l|l|l|} 
SS10 & 0.35 & 1.69 & 2.04 & 1.32 \\
\hline SS11 & 0.58 & 1.96 & 1.97 & 1.32 \\
\hline SS12 & 1.88 & 3.13 & 3.45 & 2.17 \\
\hline SS13 & 1.75 & 3.37 & 3.61 & 1.81 \\
\hline SS14 & 1.51 & 2.75 & 3.18 & 1.58 \\
\hline SS15 & 1.51 & 2.60 & 3.23 & 1.81 \\
\hline SS16 & 1.47 & 2.72 & 3.16 & 1.81 \\
\hline SS17 & 1.12 & 2.71 & 2.74 & 1.32 \\
\hline SS18 & 0.72 & 2.04 & 2.48 & 1.32 \\
\hline SS19 & 0.96 & 2.22 & 2.70 & 1.32 \\
\hline SS20 & 2.75 & 2.60 & 4.25 & 2.70 \\
\hline SS21 & 1.17 & 2.31 & 2.90 & 1.58 \\
\hline SS22 & 1.22 & 2.07 & 3.26 & 2.00 \\
\hline SS23 & 1.66 & 3.51 & 3.24 & 2.17 \\
\hline SS24 & 1.62 & 1.26 & 2.01 & 1.32 \\
\hline SS25 & 2.19 & 3.11 & 3.76 & 2.70 \\
\hline SS26 & 0.26 & 1.47 & 1.56 & 1.32 \\
\hline SS27 & 0.07 & 1.43 & 1.07 & 1.32 \\
\hline SS28 & -0.42 & 0.72 & 1.47 & 1.32 \\
\hline SS29 & 2.04 & 2.45 & 3.54 & 2.46 \\
\hline SS30 & 0.66 & 1.94 & 1.69 & 1.32 \\
\hline SS31 & 2.37 & 2.55 & 3.92 & 2.32 \\
\hline SS32 & 2.66 & 3.79 & 4.37 & 2.81 \\
\hline SS33 & 3.10 & 3.86 & 4.47 & 2.70 \\
\hline SS34 & 2.67 & 2.31 & 4.36 & 2.70 \\
\hline SS35 & 2.79 & 4.00 & 4.41 & 2.70 \\
\hline SS36 & 1.51 & 2.57 & 3.07 & 2.32 \\
\hline SS37 & 1.82 & 2.94 & 3.24 & 2.46 \\
\hline SS38 & 1.02 & 2.89 & 2.68 & 1.58 \\
\hline SS39 & 2.72 & 3.17 & 3.85 & 2.70 \\
\hline SS40 & -2.15 & -0.15 & -0.45 & 1.32 \\
\hline SS41 & -2.15 & 0.91 & -0.66 & 1.32 \\
\hline SS42 & -0.42 & 0.85 & 0.24 & 1.32 \\
\hline SS43 & -0.15 & 0.91 & 1.04 & 1.32 \\
\hline SS44 & -0.15 & 1.02 & 1.33 & 1.32 \\
\hline SS45 & -1.74 & -0.42 & -0.23 & 1.32 \\
\hline SS46 & 1.22 & 2.49 & 2.73 & 1.32 \\
\hline SS47 & 1.94 & 3.22 & 3.37 & 2.17 \\
\hline SS48 & 2.22 & 3.85 & 3.48 & 2.32 \\
\hline SS49 & 0.04 & 1.55 & 1.35 & 1.32 \\
\hline SS50 & 1.17 & 2.45 & 2.48 & 1.81 \\
\hline & & & & \\
\hline
\end{tabular}

Table 4b: summary of Geo-accumulation index calculated for selected metals in Ondo town stream sediments.

\begin{tabular}{|l|l|l|}
\hline Metal & Igeo Range & Interpretation \\
\hline $\mathrm{Cu}$ & $0-3$ & Unpolluted - highly polluted \\
\hline $\mathrm{Pb}$ & $0-4$ & Unpolluted - very highly polluted \\
\hline $\mathrm{Zn}$ & $0-4$ & Unpolluted - very highly polluted \\
\hline $\mathrm{Cd}$ & $0-2$ & Unpolluted - moderately polluted. \\
\hline
\end{tabular}




\section{CONCLUSION}

A total of 50 stream sediments samples in Ondo town were examined for $\mathrm{Cu}, \mathrm{Pb}, \mathrm{Zn}, \mathrm{Cr}, \mathrm{Ni}, \mathrm{Mn}, \mathrm{Ba}, \mathrm{Th}, \mathrm{La}$, $\mathrm{Sr}$, Co, $\mathrm{V}$ and $\mathrm{Cd}$. High concentration of metals were generally found, especially $\mathrm{Mn}, \mathrm{Zn}$, and $\mathrm{Pb}$. These indicate that these metals may be potentially hazardous to the environment. Elevated metal concentrations were found at locations close to active commercial and human waste discharges into the stream, indicating anthropogenic effect. Comparing the determined elemental result with the background result, there is a considerable elemental enrichment in the stream sediments to between 4 to 6 folds in most of the location greater than the background. Further pollution level quantification of the trace metals revealed that $\mathrm{Pb}, \mathrm{Zn}$ and $\mathrm{Cu}$ have reached significant pollutant status in the stream sediments of Ondo town as observed in the calculated geo-accumulation index which is seen that $\mathrm{Pb}$ and $\mathrm{Zn}$ are ranging from uncontaminated to very highly contaminated while $\mathrm{Cu}$ and $\mathrm{Cd}$ is ranging from uncontaminated to highly contaminated and moderately contaminated respectively.

\section{ACKNOWLEDGEMENTS}

This research was financially supported by authority of Wesley University of Science and Technology, Ondo. We gratefully appreciate their assistance.

\section{REFERENCES}

Baruah, B. P and Khare, P., 2010. Mobility of trace and potentially harmful elements in the environment from high sulfur Indian coal mines. Applied Geochemistry 25, 1621-1631

Baruah, B. P and Khare, P., 2009. Physico-chemical characterization of acidic effluent from NorthEast Indian coal mines. In: Proceedings of International Symposium on Environmental Pollution, Ecology and Human Health (ISEPEHH), 25-27 ${ }^{\text {th }}$ July (Organized by SV University, Tirupati in collaboration with USEPA; RTP, NC, USA; Savannah State University, USA). Division of Pharmacology and Toxicology, DRDE, Gwalior, India.

Eby, G. N., 2004. Principles of Environmental geochemistry, New York: Thomson, Ellis, S. \& Mellor, A

Federal Surveys, Nigeria., 1968. Topograghic map of Ondo, Sheet 263. 3000/222/6-68

Forstener, $U$ and Wittmann, G., 1983. Metal pollution in the aquatic environment. Springer, Berlin.

Gbadebo, A. M., 2007. Geochemical Characterization of rocks, soil and dust around Ewekoro cement factory, Southwestern Nigeria. A Ph.D thesis in the department of Geology submitted to the faculty of science. Pp209.
Hamzeh, M. A., Aftabi, A and Mirzaee, M., 2011. Assessing geochemical influence of traffic and other vehicle-related activities on heavy metal concentration in urban soils of Kerman city, using a GIS-base approach. Environ Geochem Health, (33): 577-594.

Lee, P. K., Yu, Y. H., Yun, S. K and Mayer, B., 2005. Metal contamination and solid phase partitioning of metals in urban roadside sediments.

Muller, G., 1979. Index of Geoaccumulation in sediments of the Rhine River. Geojournal 2: 108- 118.

Nigeria Geological Survey Agency., 2006. Generalised Geologic Map of Nigeria, 1p

Odewande, A. O and Abimbola, A. F., 2008. Concentration indices and heavy metal concentrations in Urban soil of Ibadan metropolis, Southwestern Nigeria. Environ Geochem Health, 30, $243-254$.

Olatunji A. S and Abimbola, A. F., 2010. Geochemical Evaluation of the Lagos Lagoon sediments and water. World Applied Science Journal 9, (2): 178-193.

Samarghandi, M. R., Nouri, J., Mesdaghinia, A. R., Mahvi, A. H., Naseri, S., Vaezi, F., 2007. Efficiency removal of phenol, lead and cadmium by means of $\mathrm{UV} / \mathrm{TiO}_{2} / \mathrm{H}_{2} \mathrm{O}_{2}$ processes, Int. J. Environ. Sci, Tech., 4, (1) : 10-25.

Seshan, B. R. R., Natesan, U., Deepthi, K., 2010. Geochemical and Statistical approach for evaluation of heavy metal pollution in core sediments in southeast coast of India. Int. J. Environ. Sci, Tech., 7, (2): 291-306.

Turekian, K. K and Wedepohl, L. H., 1961. Distribution of the elements in major units of the earth's crust Bullentin of Geological Society of America, (72): 778-783.

Wong, C. S. C., Li, X. D and Thornton, K., 2006. Urban environmental geochemistry of trace metals. Environmental pollution 142, $1-6$.

Yuan, H., Shen, J., Liu, E., Wang, J and Meng, X., 2011. Assessment of nutrients and heavy metal enrichment in surface sediments from Taihu Lake, a eutrophic shallow lake in China. 